\title{
PERBANDINGAN PENGARUH PERSEPSI TERDAHAP MINAT MASYARAKAT UNTUK MENGUNJUNGI DESTINASI \\ PARIWISATA HALAL PADA LIMA KABUPATEN/KOTA DI PROVINSI DAERAH ISTIMEWA YOGYAKARTA
}

\author{
Muhammad Al Faridho Awwal \\ UIN Sunan Kalijaga, Yogyakarta \\ Email: mafaalial@gmail.com \\ Dewi Wahyu Setyo Rini \\ UIN Sunan Kalijaga, Yogyakarta \\ Email: dewiwahyusetyor2208@gmail.com
}

\begin{abstract}
This study aims to examine the effect of perception on tourists' interest in halal travel in each district / city in the Special Region of Yogyakarta. There are five districts / cities tested and compared. This study uses primary data by distributing questionnaires. In this study the results of testing using the Struqtural Equation Modeling (SEM) method and processed through the Smart PLS application software v. 3 shows that people's perception of halal tourism influences their interest in halal travel. However, in Bantul and Gunung Kidul districts the concept of perception variable does not affect the perception of development while in Yogyakarta the development perception variable does not affect the attitude of halal tourism. Nevertheless, in general community perceptions of both the concept and development affect tourists' attitudes and affect tourists' interest in visiting halal tourism.
\end{abstract}

Keywords: persepsi, minat, pariwisata halal

\section{Pendahuluan}

Pada zaman sekarang pengetahuan dan kesadaran akan produk halal dari tahun ke tahun semakin meningkat. Hal tersebut menjadikan munculnya pariwisata halal sebagai fenomena baru yang sebelumnya tidak disadari siapapun (Satriana \& Faridah, 2018). Pariwisata halal yaitu jenis pariwisata yang menyediakan fasilitas dan pelayanan yang sesuai dengan hukum Islam. Fasilitas tersebut seperti fasilitas 
makanan maupun minuman dengan label halal, restoran halal, dan hotel syariah (Kemenpar, 2015). Peluang Indonesia dalam pariwisata halal ini tentu sangatlah besar mengingat Indonesia merupakan negara dengan mayoritas penduduk muslim terbesar di dunia. Hal ini ditandai dengan ditetapkannya 10 daerah di Indonesia sebagai destinasi halal, salah satunya yaitu Daerah Istimewa Yogyakarta (Indonesia Muslim Traveler Index, 2018).

Dinas Pariwisata Yogyakarta menyebutkan bahwa, realisasi jumlah kunjungan untuk wisatawan mancanegara ke DIY secara umum dari tahun 20132017 mengalami peningkatan, dengan rata-rata peningkatan sebesar 15\% (Dinas Pariwisata DIY, 2017).

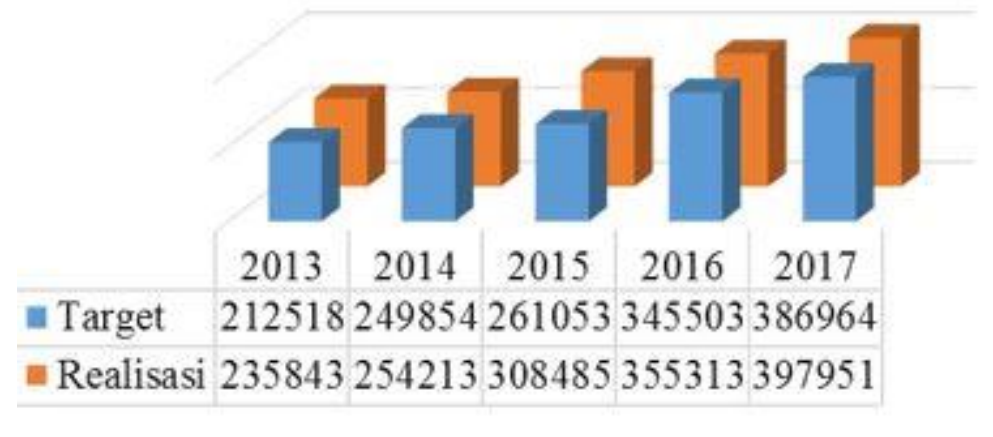

Gambar 1 Jumlah Kunjungan Wisatawan ke Yogyakarta 2013-2017 Sumber: Dinas Pariwisata DIY, 2017

Dalam berita yang dimuat di situs online ekonomisyariah.org (2017) Ketua MES (Masyarakat Ekonomi Syariah), Muliaman D Hadad, meminta MES untuk mengajak para pelaku usaha maupun masyarakat untuk menjadikan beberapa kota di DIY sebagai kota pariwisata berbasis syariah karena pariwisata ini akan memiliki dampak ekonomi yang besar bagi para pelaku usaha dan masyarakat di DIY. Dengan pengembangan wisata syariah yang berkelanjutan akan meningkatkan kontribusi ekonomi bagi pelaku bisnis yang ada di dalam industri pariwisata syariah atau pariwisata halal. Selain itu, sesuai dengan yang disampaikan oleh mantan presiden Indonesia Susilo Bambang Yudhoyono pada saat peluncuran 
Gerakan Ekonomi Syariah (GRES) di kawasan silang Monas, tanggal 17 November 2013 keberadaan ekonomi syariah memiliki banyak manfaat untuk mengurangi kerentanan antara sistem keuangan dengan sektor riil untuk menghindari penggelembungan ekonomi; menghindari pembiayaan yang cenderung berubah, dan dapat memperkuat keamanan masyarakat.

Untuk mencapai hal tersebut perlu adanya dukungan masyarakat, karena sesuai dengan hukum permintaan, menurut Karim $(2001,83)$ faktor permintaan dipengaruhi oleh minat/selera masyarakat untuk meningkatkan pertumbuhan ekonomi. Semakin tinggi minat masyarakat akan suatu barang dan jasa, semakin tinggi pula permintaan atas barang dan jasa tersebut. Sedangkan menurut suatu Theory of Reasoned Action dan Theory of Planned Behavior yang dikemukakan oleh Icek Ajzen dan Martin Fishbein dalam Achmat (1991) menyatakan bahwa penentu terpenting perilaku seseorang adalah intensi untuk berperilaku (Riza, 2017).

Dalam hal pariwisata halal, perlu adanya uji mengenai teori tersebut apakah akan relevan jika diterapkan pada masyarakat DIY. Jika memang teori tersebut benar, maka diperlukan model/konsep yang cocok untuk mengembangkan pariwisata halal dan kita harus mengetahui bagaimana ekspektasi masyarakat terhadap benefit yang akan mereka dapatkan dengan adanya pengembangan pariwisata halal. Menurut acuan GMTI (Global Travel Travel Index) dalam berita Sindonews (2016), ada tiga kelompok kriteria wisata halal yang diulas. Pertama, destinasi ramah keluarga yang mencakup keamanan umum bagi wisatawan muslim serta jumlah kedatangan wisatawan muslim. Kedua, layanan dan fasilitas di destinasi yang ramah muslim. Ketiga, kesadaran halal dan pemasaran destinasi. Selain mengenai persepsi konsep yang akan diterapkan, juga perlu mengetahui seberapa besar ekspekstasi masyarakat mengenai keuntungan/benefit yang didapatkan masyarakat terhadap pengembangan pariwisata halal yang akan dikembangkan oleh pemerintah. Dalam peneltian kali ini, penulis mencoba 
menganalisis Perbandingan Pengaruh Persepsi Terdahap Minat Masyarakat Untuk Mengunjungi Destinasi Halal Pada Lima Kabupaten/Kota Di Daerah Istimewa Yogyakarta dengan menggunakan pendekatan kuantitatif dengan menggunakan Struktural Equation Modelling (SEM).

\section{Tujuan Penelitian}

Untuk menguji pengaruh persepsi masyarakat akan wisata halal terhadap minat masyarakat untuk mengunjungi pariwisata halal. Untuk mengetahui tingkat perbedaan persepsi pada setiap kabupaten yang ada di DIY sehingga penyiapan setiap stakeholdel pada pengembangan wisata di setiap kabupaten dapat disesuaikan dengan kebutuhan pada daerah tersebut sert untuk menelaah peran ziswaf untuk pengembangan pariwisata halal.

\section{Tinjauan Pustaka}

Pariwisata halal sangat berkar dalam Islam karena setiap muslim hendaknya melakukan perjalanan (karena berbagai alasan, diantaranya terkait langsung dengan syariat Islam itu sendiri seperti haji dan umrah) (El-Gohary, 2015). Di dalam Al-Quran, banyak ayat yang mendukung untuk melakukan perjalanan yakni termaktub di Ali-Imran: 137; Al-An'am: 11; Al-Nahl: 36; Al-Naml: 69; Al'Ankabut: 20; Ar-Rum: 9 dan 42; Saba': 18; Yusuf: 109; Al-Hajj: 46; Fathir: 44; Ghafhir: 82 dan 21; Muhammad: 10; Yunus: 22; dan Al-Mulk:15. Ayat-ayat Al-Quran tersebut mendukung perjalanan dengan tujuan spritual, fisik, dan sosial (Zamani-Farahani dan Henderson, 2010).Dari ayat-ayat tersebut dapat diambil hikmah bahwa penyerahan diri yang lebih dalam kepada Allah dimungkinkan dengan melihat langsung keindahan dan karunia ciptaan-Nya, serta memahami kecilnya manusia dapat mengagungkan kebesaran Tuhan. Perjalanan dapat pula meningkatkan kesehatan dan menugurangi stres, sehingga memungkinkan untuk beribadah lebih baik. Hubungan wisatawan (tamu) dan agama juga ditegaskan, bahwa muslim 
sebagai tuan rumah harus memberikan keramah tamahan kepada wisatawan. Di dalam islam, doa safar (perjalanan) lebih dikabulkan (Hashim et al. 2007). Sehingga Islam memiliki pengaruh yang besar pada perjalanan dan mendorong pariwisata.

Wisata halal muncul dari kebutuhan wisatawan muslim sesuai ajaran Islam yakni sesuai dengan Al-Quran dan Hadits. Sehingga, Konsep wisata halal merupakan aktualisasi dari konsep ke-Islaman yakni nilai halal dan haram menjadi tolak ukur utamanya. Hal ini berarti seluruh aspek kegiatan wisata tidak terlepas dari sertifikasi halal yang harus menjadi acuan bagi setiap pelaku pariwisata (Chookaew et al. 2015). Hingga kini, belum ada prinsip-prinsip atau syarat utama wisata halal yang disepakati dan tidak banyak literatur atau praktisi yang mendiskusikan dan memaparkan hal tersebut (El-Gohary, 2016). Literatur yang mengangkat hal tersebut dapat dilihat pada Henderson (2010); Sahida et al. (2011); Battour et al. 2010; Saad et al (2014).

Berdasarkan prinsip dan atau syarat utama wisata halal diatas, beberapa prinsip dapat berseberangan dengan kepentingan lainnya khususnya pada negara-negara non-Islam yang mengembangkan wisata halal. Sehingga diperlukan diskusi dan kajian mengenai hal tersebut, oleh para peneliti, praktisi, termasuk ulama yang paham akan hal ini. Namun, dari prinsip-prinsip atau syarat utama wisata halal diatas, makanan halal, produk yang tidak mengandung babi, tidak ada minuman keras, ketersediaan fasilitas ruang ibadah, tersedianya AlQur'an dan peralatan ibadah (shalat) dikamar, petunjuk kiblat, dan pakaian staf yang sopan merupakan hal yang penting bagi wisatawan muslim (The World Halal Travel Summit, 2015). 


\section{Peluang Dan Tantangan Wisata Halal (Halal Tourism)}

Populasi muslim saat ini sekitar 30 persen dari total populasi dunia (Kim et al. 2015). Jumlah populasi muslim diperkirakan akan terus meningkat dari tahun ke tahun. Peningkatan tersebut lebih tinggi dari populasi penganut agama lainnya (Pew Research Center, 2017). Diperkirakan populasi muslim antara tahun 2015 hingga 2060 meningkat sebesar 70 persen (Gambar 1), sedangkan populasi dunia meningkat sebesar 32 persen atau jumlah total populasi dunia pada tahun 2060 sebanyak 9.6 miliar 40 orang. Hal ini juga menandakan bahwa wisatawan muslim akan terus meningkat. Pada tahun 2020, wisatawan muslim diperkirakan meningkat sebesar 30 persen dan meningkatkan nilai pengeluaran hingga 200 miliar USD (Master Card dan Crescent Rating, 2016). Adanya peningkatan wisatawan muslim merupakan peluang bagi sektor pariwisata untuk mengembangkan wisata halal. Sehingga beberapa negara mulai mengambil peluang tersebut dengan mengembangkan wisata halal, baik negara dengan mayoritas muslim maupun non-muslim seperti Jepang, Korea Selatan, Australia, dan Thailand. Diharapkan tempat-tempat wisata, hotel, restoran, maskapai penerbangan, agen perjalanan serta semua yang terlibat dalam pariwasata dapat terlibat di wisata halal. Agen perjalanan memiliki peluang wisata halal dalam berbagai bidang (Battour dan Ismail, 2016).

\section{Perspektif}

Menurut Joel M Charon pengertian perspektif adalah kerangka konseptual, perangkat asumsi, perangkat nilai dan perangkat gagasan yang mempengaruhi persepsi seseorang sehingga pada akhirnya akan mempengaruhi tindakan seseorang dalam situasi tertentu. Menurut Martono perspektif adalah cara pandang terhadap suatu masalah yang terjadi, atau sudut pandang tertentu yang digunakan dalam melihat suatu fenomena. Sedangkan menurut Ardianto dan Q-Anees perspektif adalah cara pandang atau sudut pandang kita terhadap sesuatu. 
Dapat disimpulkan perspektif sudut pandang sebenarnya dapat diartikan sebagai cara seseorang dalam menilai sesuatu yang bisa dipaparkan baik secara lisan maupun tulisan. Hampir setiap hari orang-orang selalu mengungkapkan perspektif dan sudut pandang mereka mengenai berbagai macam hal. Sebagai contoh, orang yang selalu memberikan sudut pandangnya mengenai sesuatu melalui media sosial, dengan cara memperbarui statusnya hingga mengomentari status teman atau saudaranya. Itu merupakan salah satu contoh yang terjadi dalam keseharian dimana sudut pandang seseorang dituangkan dalam sebuah tulisan.

\section{Sikap}

Menurut Sarnoff, sikap mengidentifikasikan sebagai ketersediaan untuk bisa bereaksi ataupun disebut disposition to react yang bisa dilihat secara positif. Ataupun sikap juga bisa dilihat secara negatif atau untavorably terhadap objek tertent, dalam hal ini Sarnoff mengemukakan pandangan yang dianggap luas. Menurut Soetarno, sikap yaitu sebuah pandangan atau perasaan yang diikuti oleh kecenderungan untuk bertindak terhadap obyek tertentu, kembali lagi Soetarno membawa obyek sebagai hal utama untuk pengertian sikap.

\section{Minat}

Minat seseorang terhadap suatu objek akan lebih kelihatan apabila objek tersebut sesuai sasaran dan berkaitan dengan keinginan dan kebutuhan seseorang yang bersangkutan (Sardiman, 1990: 76). Menurut Tampubolon (1991: 41) mengatakan bahwa minat adalah suatu perpaduan keinginan dan kemauan yang dapat berkembang jika ada motivasi. Sedangkan menurut Djali (2008: 121) bahwa minat pada dasarnya merupakan penerimaan akan sesuatu hubungan antara diri sendiri dengan sesuatu di luar diri. Minat sangat besar pangaruhnya dalam mencapai prestasi dalam suatu pekerjaan, jabatan, atau karir. Tidak akan mungkin 
orang yang tidak berminat terhadap suatu pekerjaan dapat menyelesaikan pekerjaan tersebut dengan baik. Minat dapat diartikan sebagai rasa senang atau tidak senang dalam menghadapi suatu objek (Mohamad Surya, 2003: 100). Minat berkaitan dengan perasaan suka atau senang dari seseorang terhadap sesuatu objek. Hal ini seperti dikemukakan oleh Slameto (2003:180) yang menyatakan bahwa minat sebagai suatu rasa lebih suka dan rasa keterikatan pada suatu hal atau aktivitas, tanpa ada yang menyuruh. Minat pada dasarnya adalah penerimaan akan suatu hubungan antara diri sendiri dengan sesuatu di luar diri. Semakin kuat atau dekat hubungan tersebut, semakin besar minat.

Penelitian ini menguji dan menganalisis terkait pengaruh persepsi terhadap minat masyarakat untuk berwisata halal. Terkait konsep tersebut, peneliti memilih konsep dari Theory of Planned Behavior (TPB) yang merupakan pengembangan dan pelengkap konstruk dari Theory of Reasoned Acttion (TRA) oleh Azjen. Menurut Lee \& Kotler (2011) pengembangan teori ini berhubungan dengan adanya target individu untuk memiliki kemungkinan yang besar terhadap adopsi suatu perilaku, apabila individu tersebutmemiliki sikap yang positif terhadap perilaku, kemudian mendapatkan persetujuan dari individu lain yang dekat dan terkait dengan perilaku tersebut dan perccaya bahwa perilaku tersebut dapat dilakukan dengan baik. Dengan menambahkan sebuah variabel pada konstruk ini, yaitu control perilaku persepsian (Perceived Behavioral Control), maka bentuk dari model teori perilaku perencanaan (Theory of Planned Behavior). Berikut skema yang ditampilkan: 


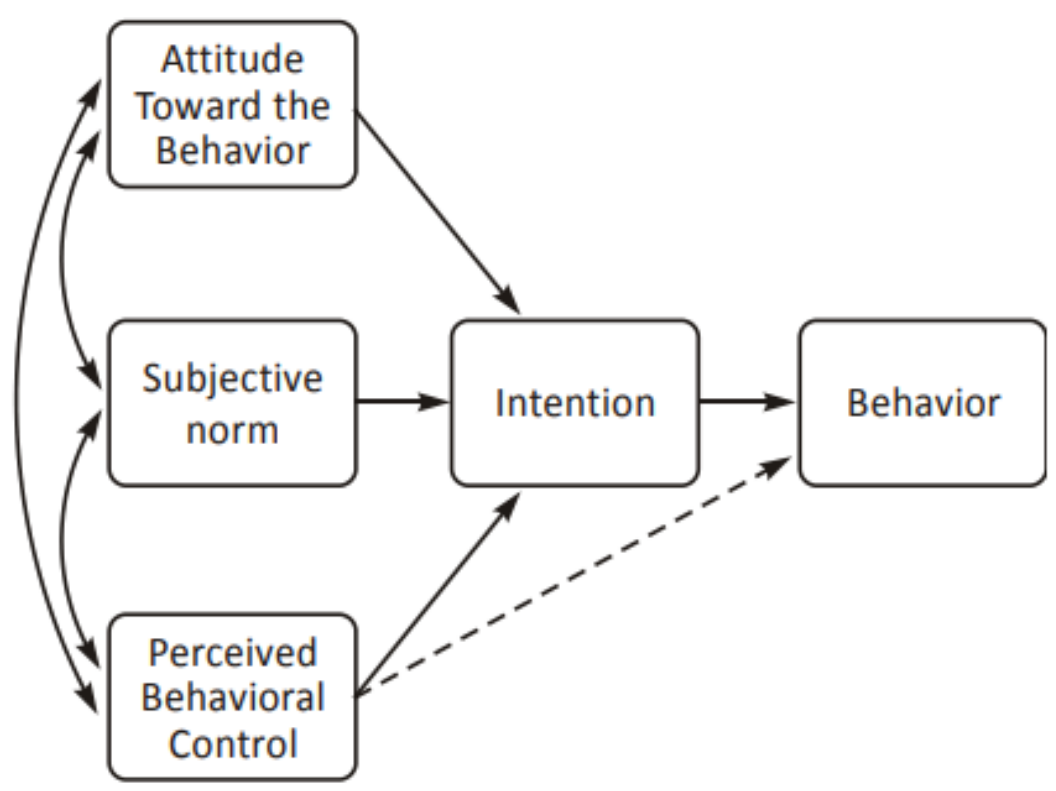

Gambar 1. Theory of Planned Behavior

Sumber: Ajzen, 2005

Dari gambar di atas, teori perilaku perencanaan memiliki 2 fitur (Muqarrabin, 2017) :

a. Teori ini mengasumsikan bahwa control persepsi perilaku mempunyai implikasi motivasional terhadap minat. Sebagian individu percaya bahwa minat tidak akan terbentuk ketika mereka tidak memiliki sumber daya yang bisa digunakan untuk bertindak, walaupun mereka mempunyai sikap yang positif terhadap perilakunya. Dengan demikian diharapkan terjadi hubungan antara control persepsi perilaku dengan minat yang tidak dimediasi oleh sikap dan norma subyektif, sehingga anak panah langsung terarah pada variabel minat perilaku.

b. Fitur kedua memungkinkan adanya suatu kinerja yang tidak hanya dipengaruhi oleh motivasional namun juga dipengaruhi oleh control yang cukup terhadap perilaku yang dilakukan. Kontrol perilaku persepsian (perceived behavioral control) dapat mempengaruhi perilaku secara tidak langsung melalui minat, dan juga dapat memprediksi perilaku secara langsung. Di model hubungan langsung ini ditunjukan dengan panah 
yang menghubungkan kontrol persepsi perilaku (perceived behavioral control) langsung ke perilaku (behavior).

Dalam penelitian ini, peneliti mencoba melakukan pengembangan konsep sesuai dengan tujuan yang akan dicapai dalam penulisan karya tulis ilmiah ini. Peneliti mengambil variabel independent berupa persepsi konsep masyarakat akan pariwisata halal. Variabel tersebut akan diuji dengan hubungannya terhadap perspektif pengembangan atau perspektif dampak dari adanya wisata halal. Kemudian, kedua variabel akan diuji terkait hubungan dan pengaruhnya terhadap variabel sikap akan wisata halal dan minat untuk mengunjungi destinasi wisata halal. Sehingga, penelitian ini memiliki konstruk pemikiran sebagai berikut:

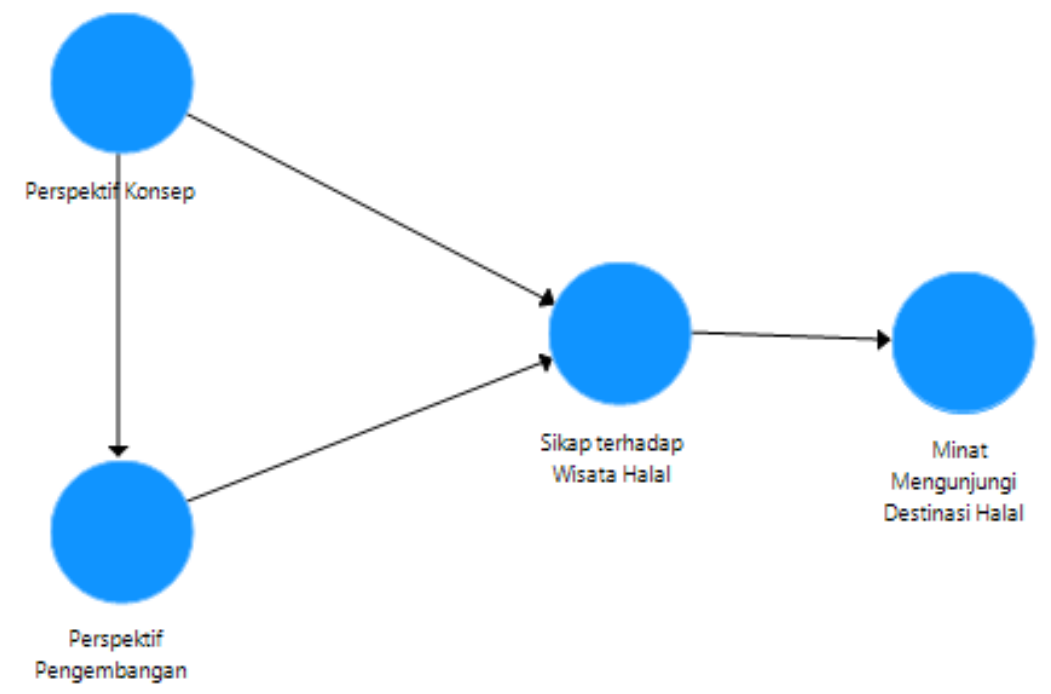

Gambar 2. Construct Pengaruh Perspektif Wisata Halal Terhadap Minat Mengunjungi Pariwisata Halal

Dalam perumusan model di atas peneliti memiliki dugaan sementara atau hipotesis yang didukung oleh beberapa teori, penelitian terdahulu serta dilengkapi dengan rasionalitas peneliti itu sendiri. Berikut pengembangan hipotesis yang digunakan: 


\section{Persepsi Konsep Pariwisata Halal dan Sikap akan Wisata Halal}

Persepsi konsep merupakan pandangan masyarakat tentang konsep pariwisata halal berupa fasilitas dan aktivitas pada suatu tempat maupun bidang. Penelitian Nur Hasanah (t.t) menunjukkan bahwa ada hubungan antara persepsi dampak pariwisata budaha, nilai personal dan sikap pariwisata budaya. Selain itu, Oktavianus Taroreh (2015) menjelaskan bahwa teori persepsi berpengaruh terhadap pengambilan keputusan dan juga sikap atau tindakan pada individu. Peneliti juga memiliki rasionalisasi akan hubungan tersebut, yang mana ketika individu memiliki persepsi yang baik akan sesuatu tentu indisvidu akan melakukan tindakan tersebut. begitupun sebaiknya. Oleh sebab itu peneliti merumuskan,

H1: Persepsi konsep berpengaruh positif terhadap sikap masyarakat akan pariwisata halal

\section{Persepsi Konsep Pariwisata Halal dan Persepsi Pengembangan Wisata Halal}

Persepsi pengembangan merupakan pandangan individu akan hasil atau dampak ketika sesuatu itu dilaksanakan. Dalam hal ini, individu memiliki pandangan tentang wisata halal, bukan hanya tentang konsepnya namun juga pandangan akan dampak apa yang akan muncul ketika wisata halal ini diimplementasikan. Persepsi pengembangan lebih dominan kepada sesuatu hal yang baru yang ingin dikemabngkan. Penelitian Lalu Adi Permana (2018) menjelaskan bahwa persepsi masyarakat NTB tentang rencana pengembangan wisata syariah sejalan dngn sikap masyarakat. Melalui teori, penelitian terdahulu dan rasionalisasi peneliti maka peneliti merumuskan hipotesiss:

H2: Persepsi konsep pariwisata halal mempengaruhi persepsi pengembangan wisata halal 


\section{Persepsi Pengembangan Wisata Halal dan Sikao akan Wisata Halal}

Persepsi pengambangan merupakan bagian dari pandangan individu akan dampak yang akan muncul ketika hal tersebut dilaksanakan. Sedangkan sikap berarti perilaku masyarakat dalam melakukan sesuatu. Ketika individu memiliki pandangan yang baik akan hasil atau dampak dari sesuatu dalam hal ini munculnya wisata syariah makan aka nada sikap positif juga yang muncul untuk mengimplementasikan wisata halal tersebut.

H3: Persepsi Pengembangan berpengaruh terhadap sikap akan wisata halal

\section{Sikap akan Wisata Halal dan Minat Mengunjungi Pariwisata Halal}

Penelitian Maria Magdalena Kumala Wardhani (2009) menjelaskan bahwa sikap konsumen pada produk memberikan pengaruh signifikan terhadap minat beli konsumen.

H4: Sikap akan wisata halal berpengaruh terhadap minat untuk mengunjungi pariwisata halal

\section{Metode Penelitian}

Metode penelitian yang digunakan dalam research ini adalah metode kuantitatif dengan menggunakan data primer. Data diambil melalui penyebaran kuesioner dengan nilai skala 1 sampai 4. Jumlah jawaban responden yang terkumpul sebanyak 435 responden dari 25 kecamatan di Yogyakarta. Pengambilan sampel menggunakan teknik cluster random sampling yakni pengambilan sampel dengan memperhatikan tingkat usia responden. Selain itu, peneliti juga akan menelaah lebih dalam terkait indicator perspektif masyarakat Yogyakarta yang mempengaruhi minat masyarakat untuk mengunjungi destinasi wisata halal. Oleh sebab itu, peneliti juga menggunakan data sekunder sebagai telaah literatur yang kuat. 
Penelitian ini menggunakan pisau analisis Structural Equation Modelling (SEM) dengan alat analisisnya menggunakan Smart PLS V. 3. Peneliti akan membandingkan hasil analisis di setiap kabupaten, sehingga informasi yang tersaji mencakup indicator apa saja yang menitikberatkan masyarakat minat untuk berwisata halal. Data yang digunakan untuk setiap kabupaten berjumlah 50 responden atau 50 data yang telah discreening sesuai dengan:

\section{Structural Equation Modelling (SEM)}

Structural Equation Model (SEM) dengan Partial Least Square (PLS)

SEM (Structural Equation Modeling) adalah suatu teknik statistik yang mampu menganalisis pola hubungan antara konstruk laten dan indikatornya, konstruk laten yang satu dengan lainnya, serta kesalahan pengukuran secara langsung. SEM memungkinkan dilakukannya analisis di antara beberapa variabel dependen dan independen secara langsung (Hair et al, 2006).

Pemilihan SEM sebagai alat analisis dipertimbangkan dari sifat keberpengaruhan antar variabel yang bersifat kompleks dan berlanjut yang tidak bisa dianalisis hanya dengan menggunakan regresi. Para ahli metode penelitian mengelompokkan SEM menjadi dua pendekatan. Pendekatan pertama disebut sebagai Covariance Based SEM (CBSEM) dan pendekatan lainnya adalah Variance Based SEM atau yang lebih dikenal dengan Partial Least Squares (PLS). SEM yang berbasis kovarian umumnya menguji kausalitas atau teori sedangkan PLS lebih bersifat predictive model. Dalam permodelan dengan tujuan prediksi memiliki konsekuensi bahwa pengujian dapat dilakukan tanpa dasar teori yang kuat, mengabaikan beberapa asumsi dan parameter ketepatan model prediksi dilihat dari nilai koefisien determinasi (Monecke \& Leisch, 2012). Adapun pengujian model structural dalam PLS sebagai berikut: 
Model Struktural (inner model)

SEM menggunakan PLS hanya mengijinkan model hubungan antar variabel yang recursif (searah) saja. Hal ini sama dengan model analisis jalur (path analysis), tidak sama dengan SEM yang berbasis kovarian yang mengijinkan juga terjadinya hubungan non-recursif (timbal-balik). Pada model struktural, yang disebut juga sebagai model bagian dalam, semua variabel laten dihubungan satu dengan yang lain dengan didasarkan pada teori substansi. Variabel laten dibagi menjadi dua, yaitu eksogenous dan endogenous. Variabel laten eksogenous adalah variabel penyebab atau variabel tanpa didahului oleh variabel lainnya dengan tanda anak panah menuju ke variabel lainnya (variabel laten endogenous).

\section{Model Pengukuran (Outer Model)}

Outer model sering juga disebut (outer relation atau measurement model) yang mendefinisikan bagaimana setiap blok indikator berhubungan dengan variabel latennya. Model pengukuran (outer model) digunakan untuk menilai validitas dan realibilitas model. Uji validitas dilakukan untuk mengetahui kemampuan instrumen penelitian mengukur apa yang seharusnya diukur (Cooper dan Schindler dalam Jogiyanto dan Abdillah 2009). Sedangkan uji reliablitas digunakan untuk mengukur konsistensi alat ukur dalam mengukur suatu konsep atau dapat juga digunakan untuk mengukur konsistensi responden dalam menjawab item pernyataan dalam kuesioner atau instrument penelitian.

\section{Evaluasi Model Struktural (Inner Model)}

Model struktural (inner model) merupakan model struktural untuk memprediksi hubungan kausalitas antar variabel laten. Melalui proses bootstrapping, parameter uji t-statistik diperoleh untuk memprediksi adanya hubungan kausalitas. Model struktural (inner model) dievaluasi dengan melihat persentase varian yang 
dijelaskan oleh nilai R-square untuk variabel dependen dengan menggunakan ukuran Stone-Geisser Q-square test (Stone, Geisser, 1974).

\section{Pembahasan}

\section{Analisis Perbandingan Persepsi Masyarakat DIY terhadap Pengaruhnya akan Minatnya untuk Mengunjungi Destinasi Wisata Halal}

Seperti sudah dijelaskan di sub bab sebelumny yang menyebutkan bahwa Daerah Istimewa Yogyakarta merupakan salah satu provinsi yang memilki daya minat tinggi sebagai tempat tujuan destinasi wisata di Indonesia. Melalui peluang tersebut perlu adanya optimalisasi peningkatan pengembangan pariwisata halal di Yogyakarta, mengingat Yogyakarta juga sebagai provinsi yang memiliki mayoritas penduduk beragama muslim. Dalam teori bisnis, sebelum perusahaan mengeluarkan produk yang akan dijualnya ke pasar, mereka akan melakukan bedah pasar untuk mengetahui keinginan konsumen sehingga perusahaan dapat menyasar pangsa pasarnya dengan tepat. Hal ini jugalah yang menjadi perhatian bagi peneliti, yang mana peneliti akan menelaah persepsi masyarakat DIY terhadap konsep pariwisata. Melalui informasi tersebut, stakeholder terkait akan mengetahui apa yang menjadi pandangan sekaligus keinginan utama dari masyarakat terhadap adanya pariwisata halal.

Pada research ini, peneliti akan melakukan telaah persepsi masyarakat sesuai dengan kabupaten yang ada di DIY. Kemudian, peneliti juga akan melakukan perbandingan terhadap hasil olah data pada persepsi masyarakat, sehingga harapannya akan ditemukan benang merah yang menyajikan informasi yang mencakup seluruh masyarakat DIY. Mengingat pengambilan data dilakukan melalui penyebaran kuesioner, oleh sebab itu perlu adanya pengujian terhadap kevalidan dan uji reliabilitas atas pertanyaan tersebut. Ketika terdapat pertanyaan yang tidak lolos uji tersebut, beberapa peneliti berpendapat agar indicator pertanyaan tersebut dibuang atau dihapuskan. Mengingat, ketika indicator pertanyaan tersbeut tidak 
dihapuskan, indicator tersebut akan mengganggu hasil uji selanjutnya terutama uji hipotesis sehingga sangat memungkinkan uji tersebut tidak akan lolos.

Berikut hasil uji validitas dan uji reliabilitas pada lima kabupaten dengan 50 responden setiap kabupatennya.

\begin{tabular}{|c|c|c|c|c|c|c|c|c|c|c|}
\hline \multirow[b]{3}{*}{$\begin{array}{l}\text { Minat } \\
\text { Mengunjungi } \\
\text { Destinasi } \\
\text { Wisata Halal }\end{array}$} & \multicolumn{2}{|c|}{ Bantul } & \multicolumn{2}{|c|}{ Gunung Kidul } & \multicolumn{2}{|c|}{ Kota Yogyakarta } & \multicolumn{2}{|c|}{ Kulon Progo } & \multicolumn{2}{|c|}{ Sleman } \\
\hline & $\begin{array}{c}\text { Cronba } \\
\text { ch'Alp } \\
\text { ha }\end{array}$ & AVE & $\begin{array}{c}\text { Cronba } \\
\text { ch'Alp } \\
\text { ha }\end{array}$ & AVE & $\begin{array}{c}\text { Cronba } \\
\text { ch'Alp } \\
\text { ha }\end{array}$ & AVE & $\begin{array}{c}\text { Cronba } \\
\text { ch'Alp } \\
\text { ha }\end{array}$ & AVE & $\begin{array}{c}\text { Cronba } \\
\text { ch'Alp } \\
\text { ha }\end{array}$ & AVE \\
\hline & 0.880 & 0.734 & 0.939 & 0.847 & 0.864 & 0.787 & 0.908 & 0.783 & 0.890 & 0.752 \\
\hline $\begin{array}{l}\text { Persepsi } \\
\text { Konsep } \\
\text { Pariwisata } \\
\text { Halal }\end{array}$ & 0.882 & 0.586 & 0.838 & 0.604 & 0.930 & 0.675 & 0.965 & 0.640 & 0.870 & 0.659 \\
\hline $\begin{array}{l}\text { Persepsi } \\
\text { Pengembanga } \\
\text { n Wisata } \\
\text { Halal }\end{array}$ & 0.851 & 0.627 & 0.907 & 0.683 & 0.825 & 0.741 & 0.917 & 0.668 & 0.885 & 0.688 \\
\hline $\begin{array}{l}\text { Sikap akan } \\
\text { Wisata Halal }\end{array}$ & 0.875 & 0.667 & 0.895 & 0.762 & 0.782 & 0.699 & 0.882 & 0.740 & 0.843 & 0.683 \\
\hline
\end{tabular}

Data di atas menunjukkan hasil uji validitas dan reliabilitas untuk semua indikator pertanyaan yang telah diuji sesuai dengan variabel yang ada. Namun, hasil di atas merupakan hasil akhir yang telah menghapus pertanyaan pertanyaan yang tidak lolos salah satu atau kedua uji tersebut. Hasil uji reliabilitas dapat dilihat pada kolom Cronbach's Alpha sedangkan uji validitas dapat dilihat pada kolom Average Variance Extracted (AVE). Indikator pertanyaan dikatakan lolos uji validitas ketika nilainya lebih daro 0.8 atau $80 \%$, sedangkan untuk lolos uji validitas nilai hasil ujinya harus lebih dari $0 . .5$ atau 50\%. Berikut peneliti sajikan indikator pertanyaan yang lolos uji validitas dan uji reliabilitas (hasil uji asli disajikan dalam halaman lampiran): 
a. Variabel Persepsi terhadap Pariwisata Halal

Pariwisata halal adalah pariwisata yang menyediakan:

\begin{tabular}{|c|c|c|c|c|}
\hline Bantul & Kulon Progo & Gunung Kidul & $\begin{array}{c}\text { Kota } \\
\text { Yogyakarta }\end{array}$ & Sleman \\
\hline $\begin{array}{l}\text { - Aktivitas yang } \\
\text { tidak } \\
\text { melanggar } \\
\text { syariat Islam } \\
\text { - Pemandangan } \\
\text { yang indah } \\
\text { - Ruang khusus } \\
\text { menyusui } \\
\text { - Tempat } \\
\text { sampah yang } \\
\text { memadai } \\
\text { - Akses jalan } \\
\text { masuk yang } \\
\text { memadai } \\
\text { Akses } \\
\text { informasi } \\
\text { lokasi secara } \\
\text { online } \\
\text { - Petugas medis } \\
\text { atau pusat } \\
\text { kesehatan } \\
\text { Rambu } \\
\text { petunjuk } \\
\text { keselamatan } \\
\text { - Staf yang } \\
\text { disiplin dan } \\
\text { menghargai } \\
\text { nilai ke- } \\
\text { Islaman }\end{array}$ & $\begin{array}{l}\text { - Masjid/mushola yang } \\
\text { bersih } \\
\text { - Masjid/mushola yang } \\
\text { selalu } \\
\text { mengumandangkan } \\
\text { adzan } \\
\text { - Tempat wudhu yang } \\
\text { memadai } \\
\text { - Tempat wudhu khusus } \\
\text { wanita } \\
\text { - Kamar mandi yang bersih } \\
\text { - Kamar mandi yang } \\
\text { terpisah antara laki-laki } \\
\text { dan perempuan } \\
\text { - Tempat parkir yang } \\
\text { memadai } \\
\text { - Tempat sampah yang } \\
\text { memadai } \\
\text { - Akses jalan masuk yang } \\
\text { memadai } \\
\text { - Akses transportasi umum } \\
\text { yang terjangkau } \\
\text { - Petugas keamanan } \\
\text { - Petugas medis atau pusat } \\
\text { kesehatan } \\
\text { - Pusat informasi dengan } \\
\text { pengeras suara } \\
\text { - Rambu petunjuk } \\
\text { keselamatan } \\
\text { - Pemandu wisata yang } \\
\text { disiplin dan menghargai } \\
\text { nilai ke-Islaman } \\
\text { - Teaf yang disiplin dan } \\
\text { menghargai nilai ke- } \\
\text { Islaman } \\
\text { dengang bersih } \\
\text { dengan sertifikasi halal }\end{array}$ & $\begin{array}{l}\text { - Kamar mandi } \\
\text { yang terpisah } \\
\text { antara laki- } \\
\text { laki dan } \\
\text { perempuan } \\
\text { - Petugas } \\
\text { keamanan } \\
\text { - Pusat } \\
\text { informasi } \\
\text { dengan } \\
\text { pengeras } \\
\text { suara } \\
\text { - Pemandu } \\
\text { wisata yang } \\
\text { disiplin dan } \\
\text { menghargai } \\
\text { nilai ke- } \\
\text { Islaman } \\
\text { Tempat } \\
\text { makan/warun } \\
\text { g yang bersih }\end{array}$ & $\begin{array}{l}\text { - } \text { Tempat } \\
\text { parkir yang } \\
\text { memadai } \\
\text { - Tempat } \\
\text { sampah } \\
\text { yang } \\
\text { memadai } \\
\text { - Akses jalan } \\
\text { masuk yang } \\
\text { memadai } \\
\text { - Akses } \\
\text { transportasi } \\
\text { umum yang } \\
\text { terjangkau } \\
\text { - Petugas } \\
\text { keamanan } \\
\text { - Petugas } \\
\text { medis atau } \\
\text { pusat } \\
\text { kesehatan } \\
\text { Rambu } \\
\text { petunjuk } \\
\text { keselamatan } \\
\text { Tempat } \\
\text { makan/war } \\
\text { ung yang } \\
\text { bersih }\end{array}$ & 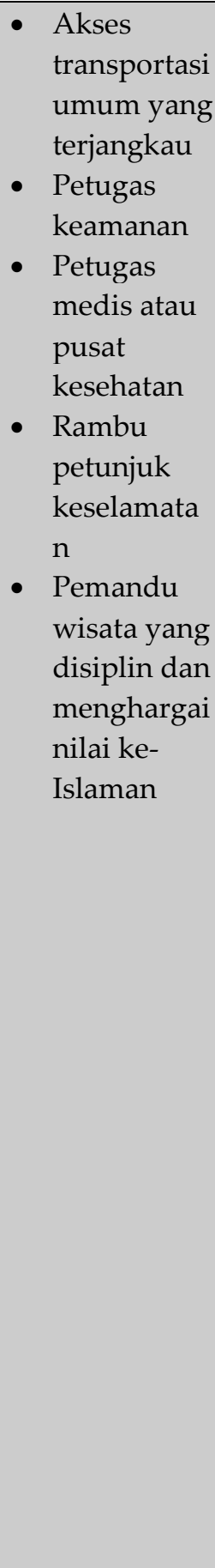 \\
\hline
\end{tabular}


Dalam hal ini, peneliti mencoba memetakan semua indicator pertanyaan berdasarkan sub bidang yang mencakup semua pertanyaan. Peneliti mengambil lima sub bidang untuk memetakan indicator pertanyaan yang ada, yakni religiusitas, destinasi, fasilitas, informasi dan akomodasi. Sub bidang in menyesuaikan dengan standarisasi oleh Global Mouslim Travel Index (GMTI) yang menyebutkan bahwa terdapat tiga indicator standarisasi halal yang harus dipenuhi yaitu:

1) Destinasi ramah keluarga

2) Layanan dan fasilitas yang ramah muslim

3) Kesadaran halal dan pemasaran destinasi

Kemudian, tiga indicator tersebut dijabarkan menjadi sebelas indicator lainnya yakni : destinasi ramah keluarga, keamanan umum \& muslim, jumlah keatangan wisatawan muslim, makanan dan jaminan halal, akses ibadah, fasilitas, akomodasi, kemudahan komunikasi, jangkauan dan kesadaran kebutuhan muslim, konektivitas tranportasi udara, dan persyaratan visa.

Berdasarkan hasil di atas, untuk variabel persepsi konsep masyarakat Bantul masih tersebar di lima indicator yang peneliti pilih, sedangkan di kabupaten Kulon Progo persepsi masyarakat akan wisata halal di dominasi komponen religiusitas dan diikuti pada bidang fasilitas dan akomodasi. Kemudian di Kabupaten Gunung Kidul persepsi masyarakat akan pariwisata halal terfokus pada religiusitas, fasilitas dan informasi. Sedangkan masyarakat Kota Yogyakarta berperspektif pariwisata halal ada pada fasilitas yang disediakan dan akomodasi. Yang terakhir masyarakat Kabupaten Sleman mendominasi perspektifnya akan wisata halal pada akomodasi, fasilitas dan religiusitas.

Jika disimpulkan, dari kelima kabupaten perspektif utama masyarakat DIY akan pariwisata halal terletak pada fasilitas yang disediakan. Seperti kamar mandi 
yang bersih, parkir yang memadai, akses keamanan, akses kesehatan dan fasilitas lainnya. Melalui informasi ini, dapat disimpulkan bahwa perlu ada peningkatan optimal pada penyediaan fasilitas di pariwisata halal, baik fasilitas berupa jasa maupun fasilitas tempat.

b. Variabel Persepsi terhadap Pengembangan Pariwisata Halal

Pariwisata halal perlu dikembangkan di DIY untuk:

\begin{tabular}{|c|c|c|c|c|}
\hline Bantul & Kulon Progo & Gunung Kidul & Kota Yogyakarta & Sleman \\
\hline $\begin{array}{l}\text { - Membuka } \\
\text { peluang kerja } \\
\text { bagi } \\
\text { masyarakat } \\
\text { DIY } \\
\text { Meningkatkan } \\
\text { pendapatan } \\
\text { penduduk DIY } \\
\text { Membantu } \\
\text { berkembangny } \\
\text { a sektor usaha } \\
\text { lain } \\
\text { Memperkuat } \\
\text { budaya yang } \\
\text { ada DIY } \\
\text { Mengurangi } \\
\text { kejahatan dan } \\
\text { masalah social }\end{array}$ & 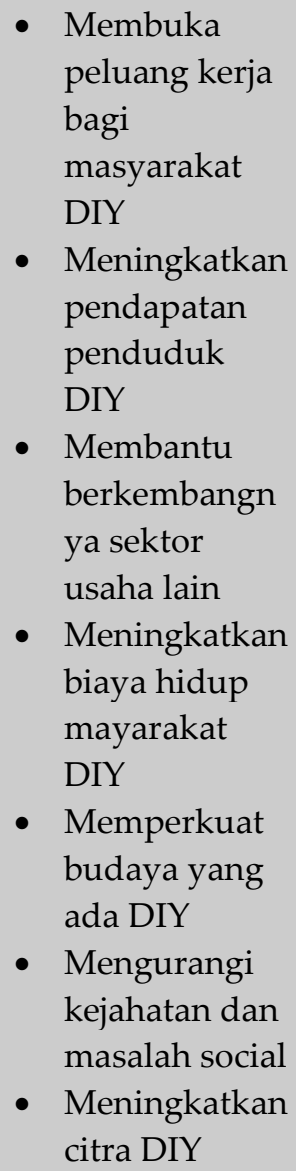 & 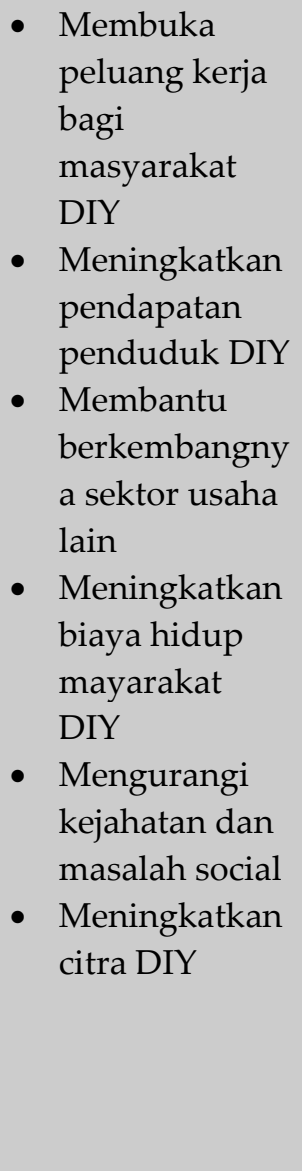 & $\begin{array}{l}\text { - Membuka } \\
\text { peluang kerja } \\
\text { bagi } \\
\text { masyarakat } \\
\text { DIY } \\
\text { - Meningkatkan } \\
\text { pendapatan } \\
\text { penduduk } \\
\text { DIY } \\
\text { Meningkatkan } \\
\text { biaya hidup } \\
\text { mayarakat } \\
\text { DIY }\end{array}$ & $\begin{array}{l}\text { - Perspektif } \\
\text { pengembanga } \\
\mathrm{n} \\
\text { - Membuka } \\
\text { peluang kerja } \\
\text { bagi } \\
\text { masyarakat } \\
\text { DIY } \\
\text { - Meningkatkan } \\
\text { pendapatan } \\
\text { penduduk } \\
\text { DIY } \\
\text { Membantu } \\
\text { berkembangn } \\
\text { ya sektor } \\
\text { usaha lain } \\
\text { Mengurangi } \\
\text { kejahatan dan } \\
\text { masalah social } \\
\text { Meningkatkan } \\
\text { citra DIY }\end{array}$ \\
\hline
\end{tabular}

Pada indicator pertanyaan ini, jika dilihat dari hasil olah data yang dilakukan oleh peneliti, semua masyarakat yang tersebar di kelima kabupaten menghilangkan atau menghindari munculnya dampak negatif dan dampak yang masih ambigu. Dampak negatif yang dihindari seperti munculnya kemacetan, meningkatkan 
kepadatan, meningkatkan biaya hidup, memberikan kesempatan pada pihak asing serta mempengaruhi gaya hidup masyarakat. Masyarakat memiliki perspektif bahwa munculnya wisata halal akan membawa dampak positif bagi amsyarakat terutama terkait citra DIY serta meningkatnya pendapatan masyarakat DIY.

Melalui informasi ini, diharapkan stakeholder terkait mempertimbangkan setiap kebijakan yang diambil, terutama yang menyangkut pembangunan fasilitas yang dapat memunculkan dampak yang merugikan masyarakat luas.

c. Variabel Sikap terhadap Wisata Halal

\begin{tabular}{|c|c|c|c|c|}
\hline Bantul & Kulon Progo & Gunung Kidul & Kota Yogyakarta & Sleman \\
\hline $\begin{array}{l}\text { - Saya suka } \\
\text { memilih destinasi } \\
\text { wisata halal } \\
\text { sebagai tujuan } \\
\text { berlibur } \\
\text { - Berwisata secara } \\
\text { halal merupakan } \\
\text { pilihan saya } \\
\text { - Pariwisata halal } \\
\text { penting bagi saya } \\
\text { Pariwisata halal } \\
\text { memenuhi } \\
\text { ekspektasi saya } \\
\text { - Saya lebih } \\
\text { memilih rumah } \\
\text { makan dengan } \\
\text { logo halal saat } \\
\text { berwisata }\end{array}$ & 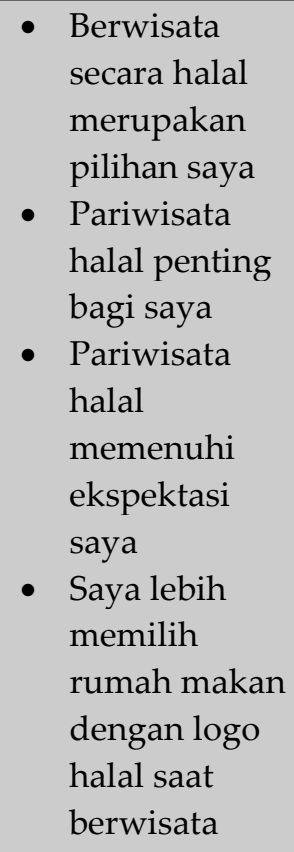 & $\begin{array}{l}\text { - Saya suka } \\
\text { memilih } \\
\text { destinasi } \\
\text { wisata halal } \\
\text { sebagai tujuan } \\
\text { berlibur } \\
\text { - Berwisata } \\
\text { secara halal } \\
\text { merupakan } \\
\text { pilihan saya } \\
\text { - Pariwisata } \\
\text { halal penting } \\
\text { bagi saya } \\
\text { - Pariwisata } \\
\text { halal } \\
\text { memenuhi } \\
\text { ekspektasi } \\
\text { saya }\end{array}$ & $\begin{array}{l}\text { - Saya suka } \\
\text { memilih } \\
\text { destinasi } \\
\text { wisata halal } \\
\text { sebagai tujuan } \\
\text { berlibur } \\
\text { - Berwisata } \\
\text { secara halal } \\
\text { merupakan } \\
\text { pilihan saya } \\
\text { Pariwisata } \\
\text { halal penting } \\
\text { bagi saya }\end{array}$ & 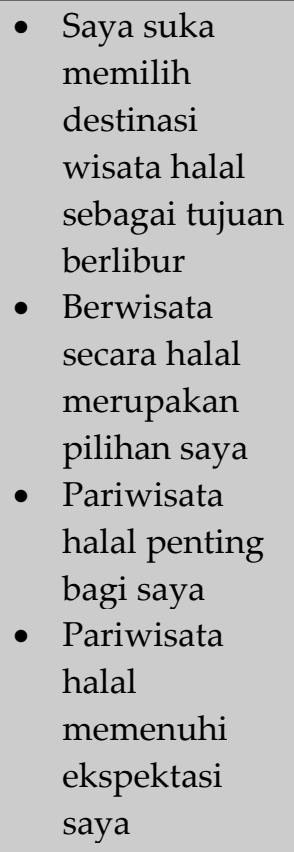 \\
\hline
\end{tabular}

Indicator pertanyaan terkait sikap masyarakat akan munculnya pariwisata halal membawa nilai positif dengan masyarakat DIY, di mana hampir seluruh masyarakat DIY akan memilih destinasi wisata halal sesuai dengan perspektif yang diambil. Namun, untuk pertanyaan pemilihan makanan berlabel halal pada kabupaten Gunung Kidul, Yogyakarta dan Sleman tidak memilih hal tersbeut. Mindset masyarakat bahwa senua makanan di DIY pasti halal karena mayoritas masyarakatnya yang muslim. Melalui informasi ini, stakeholder perlu meningkatkan kesadaran masyarakat akan pentingnya sertifikasi halal pada makanan. 
d. Variabel Minat Mengunjungi Destinasi Wisata Halal

\begin{tabular}{|c|c|c|c|c|}
\hline Bantul & Kulon Progo & Gunung Kidul & Kota Yogyakarta & Sleman \\
\hline 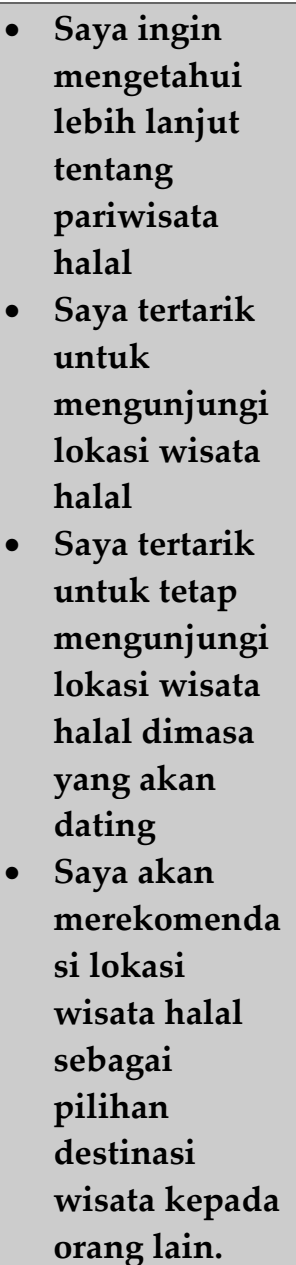 & 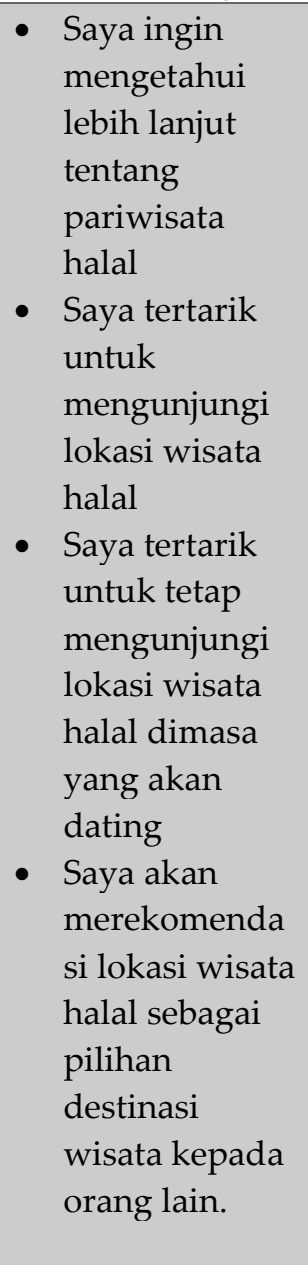 & 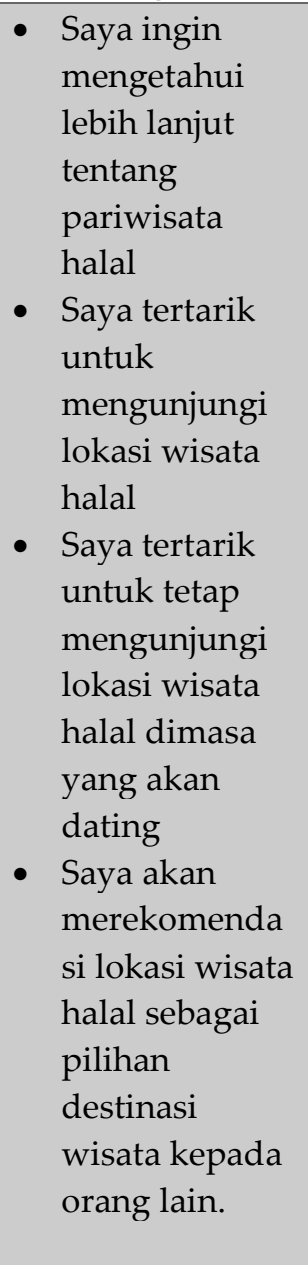 & 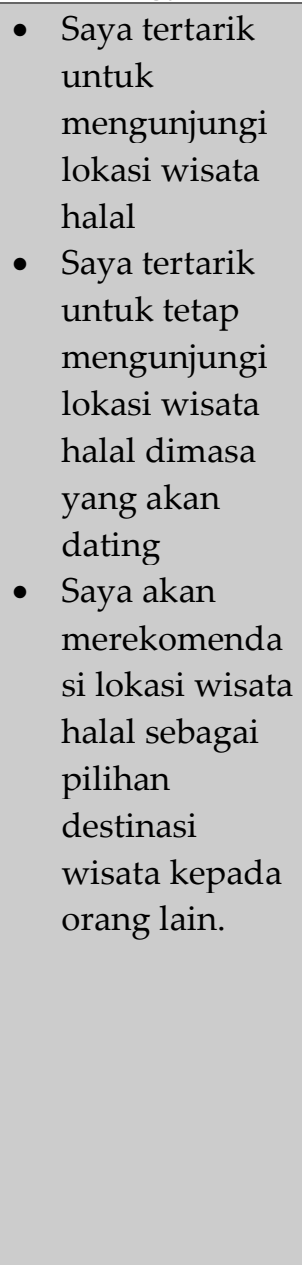 & 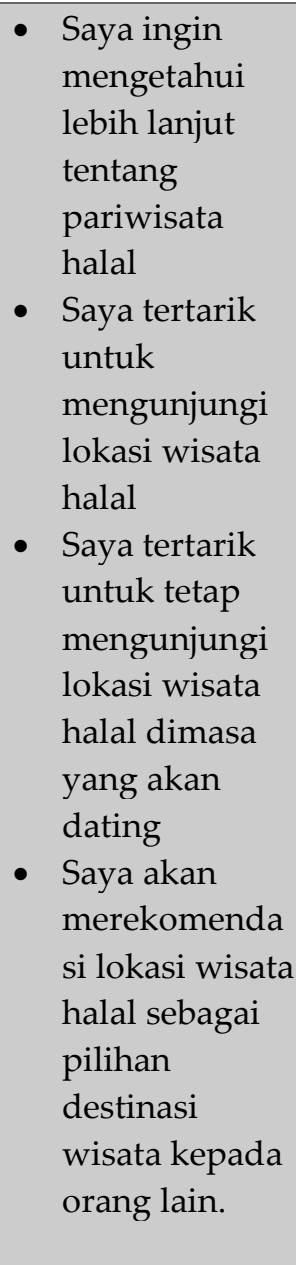 \\
\hline
\end{tabular}

Indikator pertanyaan pada variabel minat menunjukkan seberapa pengaruhnya variabel variabel sebelumnya terhadap keputusan untuk mengunjungi destinasi wisata halal. Berdasarkan indikator pertanyaan yang disajikan ke masyarakat, hampir semua masyarakat DIY memiliki minat untuk mengetahui lebih lanjut tentang pariwisata halal, memiliki minat untuk mengunjungi bahkan memiliki keinginan untuk merekomendasikan wisata halal kepada orang lain.

Melalui telaah pada setiap variabel di atas, peneliti dapat menyimpulkan bahwa terdapat perbedaan kuat di setiap kabupaten tekait perspektifnya tehadap pariwisata halal. Perbedaan tersebut dapat muncul karena berbagai hal, seperti kondisi lingkungkan, kondisi pendidikan dan faktor lainnya. 


\section{Analisis Perbandingan Hipotesis Setiap Kabupaten di DIY}

Melanjutkan pembahasan di sub bab sebelumnya terkait uji hipotesis pada setiap kabupaten. Data peneliti menunjukkan hasil sebagai berikut:

Tabel. Hasil Olah Data Uji Hipotesis Kelima Kabupaten

\begin{tabular}{|lccccc|}
\hline & Bantul & $\begin{array}{c}\text { Gunung } \\
\text { Kidul }\end{array}$ & $\begin{array}{c}\text { Kota } \\
\text { Yogyakarta }\end{array}$ & $\begin{array}{c}\text { Kulon } \\
\text { Progo }\end{array}$ & Sleman \\
\hline $\begin{array}{l}\text { Persepsi Konsep - Persepsi } \\
\text { Pengembangan }\end{array}$ & 0.000 & 0.000 & 0.000 & 0.000 & 0.000 \\
Persepsi Konsep - Sikap & 0.988 & 0.126 & 0.043 & 0.000 & 0.010 \\
Persepsi Pengembangan - Sikap & 0.003 & 0.006 & 0.053 & 0.006 & 0.000 \\
Sikap - Minat Mengunjungi Wisata Halal & 0.000 & 0.000 & 0.000 & 0.000 & 0.000 \\
\hline
\end{tabular}

Berdasarkan hasil uji hipotesis di atas, terdapat tiga kabupaten memiliki hasil hipotesis tidak signifikan. Pada kabupaten Bantul, persepsi konsep tidak mempengaruhi sikap masyarakat akan wisata halal. Jika dihubungkan dengan indicator pertanyaan sebelumnya, dilihat bahwa indicator jawaban pertanyaan untuk variabel perspektif konsep masih meluas. Masyarakat belum memiliki padangan yang sama terkait perspektif utama akan pariwisata halal. Hal ini pula yang menjadikan perspektif konsep tidak mempengaruhi sikap. Ketika individu tidak memiliki pandangan khusus tentang pariwisata halal maka akan muncul keputusan sikap yang tidak tegas, sehingga individu tersebut masih ragu ragu untuk menyikapi hal tersebut.

Alasan itu pula yang menyebabkan uji pada kabupaten Gunung Kidul menghasilkan nilai yang tidak signifikan pada hipotesis persepsi konsep terhadap sikap. Kemudian, untuk hipotesis persepsi pengembangan yang tidak signifikan terhadap sikap pada Kota Yogyakarta, hal ini dapat ditelaah dari banyaknya indicator pertanyaan persepsi pengembangan yang dihapuskan. Masyarakat kota Yogyakarta belum memiliki pandangan atau keyakinan bahwa munculnya wisata halal akan membawa dampak pada pengembangan sektor usaha, citra DIY dan 
budaya DIY. Dengan demikian, wajar kiranya jika uji hipotesisi ini tidak signifikan. Oleh sebab itu, perlu adanya penguatan pandangan pada masyarakat baik di Kabupaten Bantul, Gunung Kidul dan Kota Yogyakarta bahwa parisiwata halal mampu meningkatkan perekonomian Indonesia terutama perekonomian di DIY.

\section{Optimalisasi ZISWAF dalam Peningkatan Pariwisata Halal di DIY}

ZISWAF merupakan instrumen islam yang memiliki potensi tinggi dalam meningkatkan kesejahteraan di Indonesia. Namun instrumen ini tidak dapat berdiri sendiri, mengingat melihat histrory yang ada peran ziswaf belum maksimal karena belum adanya sinergi dari berbagai pihak. Dengan adanya potensi pariwisata halal dan hasil penelitian yang menunjukkan bahwa sebagian besar persepsi masyarakat akan pariwisata halal terfokus pada fasilitas. Sehingga perlu adanya optimalisasi pada peningkatan fasilitas untuk menunjang posisi pariwisata halal. Melalui inztrumen wakaf baik tunai maupun tanah, optimalisasi fasilitas dapat terealisasikan. Melalui produktivitas wakaf untuk digunakan dalam menunjang fasilitas pariwisata halal tentu akan meningkatkan pariwisata halal tanpa adanya pengeluaran berlebih dari stakeholder terkait. Oleh sebab itu, penguatan sinergi dari berbagai stakeholder sangat penting.

\section{Kesimpulan dan Saran}

Daerah Istimewa Yogyakarta merupakan salah satu provinsi di Indonesia yang memiliki daya tarik wisatawan tertinggi di Indonesia. Hal tersebut ditunjukkan dengan adanya kenaikan jumlah wisatawan setiap tahunnya. Indonesia sebaga negara dengan mayoritas muslim sedang mengoptimalkan potensi pariwata dengan prinsip syariahh. Oleh sebab itu, perlu adanya pengkajian khusus apakah munculnya pariwisata halal di Indonesia dapat berkorelasi positif dengan kondisi pariwisata di DIY ketika pariwisata ini diimplementasikan. Melalui data tersebut, peneliti mencoba menguji minat masyarakat DIY melalui persepsinya akan wisata 
halal. Penelitian dilakukan pada lima kabupaten yang terdapat di DIY, yang mana tujuan utama penelitian ini untuk mengetahui minat masyarakt DIY dilihat dari pemetaan di setiap kabupatennya. Hasil pengujian menggunakan metode Struqtural Equation Modelling (SEM) dan diolah melalui software aplikasi Smart PLS v. 3 menunjukkan bahwa persepsi masyarakat akan wisata halal berpengaruh terhadap minatnya untuk berwisata halal. namun, pada kabupaten Bantul dan Gunung Kidul variabel persepsi konsep tidak berpengaruh terhadap persepsi pengembangan sedangkan di Kota Yogyakarta variabel persepsi pengembangan tidak berpengaruh terhadap sikap akan wisata halal. namun walaupun demikian, secara umum persepsi masyarakat baik dari konsep maupun pengembangan berpengaruh terhadap sikap masyarakat dan berpengaruh terhadap minat masyarakat untuk mengunjungi pariwisata halal.

Semoga melalui penelitian ini stakeholder terkait dapat mendapatkan informasi terkait kebutuhan masyarakat baik dari penyediaan fasilitas maupun pada pemunculan dampak yang akan mempengaruhi masyarakat. Semoga aka nada penelitian yang lebih lengkap dari sekedar penelitian ini sehingga mampu memberikan informasi secara lebih valid dan relevan.

\section{Daftar Pustaka}

Ajzen, I. 2005. Attitudes, Personality and Behavior, (2 ${ }^{\text {nd }}$ edition), Berkshire, UK: Open University Press-McGraw Hill Education.

Battour, M., Battor, MM, dan Ismail MN. 2012. The Mediating Role of Tourist Statisfaction: A Study ofMuslim Tourists in Malaysia. Journal of Travel and Tourism Marketing..

Battour, M, dan Ismail, MN. 2016. Halal Tourism: Concepts, Practises, Challengesand Future. Tourism Management Perspective. 19: 150-154

Battour, M., Ismail, MN, dan Battor, M. 2010. Toward a Halal Tourism Market. Tourism Analysis. 15(4): 461-470. 
Chookaew, S., Chanin, O., Charatarawat, J., Sriprasert, P, dan Nimpaya, S. 2015. Increasing Halal Tourism Potential at Andaman Gulf in Thailand for Muslim Country. Journal of Economics, Business and Management. 3(7): 739-741.

Dinas Pariwisata DIY. 2017. Statistik Kepariwisataan 2017. Yogyakarta: Dinas Pariwisata DIY.

Eka \& Hayyun. Halal Tourism: Development, Chance And Challenge. Journal of Halal Product and Research (JHPR) Vol. 01 No.02, Mei-November 2018

El-Gohary, H. 2016. Halal Tourism, is it Really Halal?. Tourism Management Perspective. 19: 124-130.

Henderson, JC. 2010. Sharia-compliant hotels. Tourism and Hospitality Research. 10(3)

Indonesia Muslim Traveler Index. 2018. 10 Daerah Destinasi Halal Indonesia.Jakarta: Kemenpar RI.

Jogiyanto. Sistem Informasi Keperilakuan. Edisi Revisi. Yogyakarta: Penerbit ANDI, 2008.

Kemenpar. (2015). Laporan Akhir Kajian Pengembangan Wisata Syariah. Jakarta: Kementerian Pariwisata RI. Retrieved from Kemenpar RI: www.kemenpar.go.id

Master Card and Crescent Rating. 2016. Global Muslim Travel Index 2016. Diakses November 2018 pada https://www.crescentrating.com/reports/mastercard-crescentrating-globalmuslim-travel-index-gmti-2016.html.

Monecke, Armin dan Friedrich Leisch. 2012. SEMPLS: Structural Equation Modeling Using Partial Least Squares. Journal of Statistical Software, Volume 48, Issue 3, p. 1-32.

Muqarrabin, Alex Maulana. 2017. “Teori yang Biasa Digunakan untuk Mengukur Perilaku Konsumen (Theory of Planned Behavior)". Artikel Publikasi School of Business \& Management pada 09 Maret 2019

Sahida, W., Rahman, SA., Awang, K., dan Man YC. 2011. The Implementation of Shari'ah Compliance Concept Hotel: De Palma Hotel Ampang, Malaysia. 2nd International Conferences Humanities. Singapore: Historical and Social Sciences. 
Satriana, E. D., \& Faridah, H. D. 2018. Wisata Halal: Perkembangan, Peluang, dan Tantangan. Journal of Halal Product and Research (JHPR), 01 , 33.

Stone, M. 1974. "Cross Validatiry Choice and Assement of Statistical Predictions:Journal of the Royal Statistical Society. Series B. 36 (2), pp.111-133.

Suantara, I Gusti Putu Endra. 2014. "Pengaruh Selera dan Harga Terhadap Keputusan Konsumen dalam Pembelian Sepeda Motor Honda di Kabupaten Buleleng". Jurnal V1. 4 No.1.

The World Halal Travel Summit. 2015. Halal Tourism- An Overview, The World Halal Travel Summit and Exhibition 2015. Diakses pada November 2018 pada http://whtsexpo.com/.

Zamani-Farahani, H, dan Henderson, JC. 2010. Islamic Tourism and Managing Tourism Development in Islamic Societies: The Cases of Iran and Saudi Arabia. International Journal of Tourism Research.

\section{Profil Penulis}

Muhammad Al Faridho Awwal lahir di Kotabaru, 19 Oktober 1997. SD dan SMP ditempuh di kota kelahiran dan jenjang SMA di tempuh di Kota Banjarmasin. Sekarang Penulis sedang menempuh pendidikan S1 Manajemen Keuangan Syariah di UIN Sunan Kalijaga Yogyakarta. Penulis aktif pada organisasi Forum Studi Ekonomi dan Bisnis Islam (ForSEBI) yang berada dibawah naungan Forum Silaturahim Studi Ekonomi Islam (FoSSEI). Penulis juga aktif menulis beberapa artikel baik ilmiah maupun opini di berbagai tempat.

Dewi Wahyu Setyo Rini, kelahiran Kendal, 22 Agustus 1998. Sekarang sedang menempuh pendidikan S1 Manajemen Keuangan Syariah di UIN Sunan Kalijaga Yogyakarta. Penulis juga aktif menulis artikel baik ilmiah maupun opini diberbagai tempat. Tergabung dalam organisasi Forum Studi Ekonomi dan Bisnis Islam (ForSEBI) yang berada dibawah naungan Forum Silaturahim Studi Ekonomi Islam (FoSSEI) juga membuat khazanah keilmuan dari penulis semakin kaya daripada sebelumnya. 